\title{
Evaluation of silver nanoparticles toxicity in Daphnia magna: Comparison of chemical and green biosynthetic productions
}

\author{
Z Tulaby Dezfuly ${ }^{1}$, M Alishahi ${ }^{1 *}$, A Aramoon ${ }^{1}, \mathrm{~S}$ Mashjoor ${ }^{2}$ \\ ${ }^{1}$ Department of Clinical Sciences, Faculty of veterinary, Shahid Chamran University of Ahvaz, Ahvaz, Iran \\ ${ }^{2}$ Department of Marine biology, Faculty of Marine Science and Technology, Hormozgan University, Bandar \\ Abbas, Iran
}

Received: June 2017

Accepted: October 2017

\begin{abstract}
Recently nanoparticles, particularly silver Results showed that all nanosilver (regardless of nanoparticles, are broadly used in industry, hence the contamination of the environment with AgNPs has caused considerable concern. In this study, the toxicity of biosynthetic nanosilver produced by two macroalgae: Sargassum boveanum and Ulva flexuosa extracts were compared with chemical nanosilver in Daphnia magna. Size and quality of nanoparticles evaluated by $\mathrm{TEM}^{1}$, FT-IR ${ }^{2}$ spectrum, and Particle size analyzer. The acute toxicity test was evaluated following the $\mathrm{OECD}^{3}$ and Test guideline No: 211. D. magna were reproduced using parthenogenesis from a single individual according to OECD guideline. Then Daphnia exposed to eight serial dilutions of each nanosilver in triplicates for 48 hours. The mortality rate after $12 \mathrm{~h}, 24 \mathrm{~h}, 36 \mathrm{~h}$, and $48 \mathrm{~h}$ were their synthesis origin) were toxic in Daphnia and acute toxicity of this nanosilver was different $(\mathrm{p}<0.05)$. The $48 \mathrm{~h} \mathrm{LC}_{50}$ of SPN, UPN, and CPN in Daphnia were $1.03,3.24$ and $0.03 \mathrm{mg} \mathrm{L}^{-1}$ respectively. The mortality rate in D. magna enhanced in all tested groups, along with increasing nanosilver concentration and exposure time duration. Highest toxicity belongs to chemical nanosilver $\left(\mathrm{LC}_{50}=0.03 \mathrm{mg} \mathrm{\textrm {L } ^ { - 1 }}\right.$ ), which was 30 and 100 times more toxic than SP $\left(\mathrm{LC}_{50}=1.03\right)$ and $\mathrm{UP}\left(\mathrm{LC}_{50}=3.24 \mathrm{mg} \mathrm{L}^{-1}\right)$ respectively. According to the high toxicity of chemosynthetic nanosilver compare to biosynthetic ones, biosynthetic nanoparticles are highly recommendable and environmentally friendly alternative to chemical oriented nanoparticles.
\end{abstract} recorded and analyzed using probit software.

Correspondence: $M$ Alishahi, Department of Clinical Sciences, Faculty of veterinary, Shahid Chamran University of Ahvaz, Ahvaz, Iran. (e-mail:

Keywords: Nanosilver, Daphnia magna, Sargassum boveanum, Ulva flexuosa, Biosynthetic.

alishahim@scu.ac.ir).

\footnotetext{
${ }^{1}$ Transmission Electron Microscopy

${ }^{2}$ Frustrated Total Internal Reflection

${ }^{3}$ Organization for Economic Cooperation and Development
} 


\section{Introduction}

Silver nanoparticles (AgNPs) are widely used as spectrally selective coatings for solar energy absorption, chemical catalysts and especially for antimicrobial sterilization. After their discharge, AgNPs will most likely enter the ecosystems and may produce a physiological reaction in various animals, maybe changing their health, and finally changing their densities or community populations. Open access literature regarding the toxicity of nanoparticles is still developing, and gaps still exist in our information of this area (Hedayati, Kolangi, Jahanbakhshi \& Shaluei 2012).

Biosynthesis of metallic nanoparticles is a fairly innovative emerging extent of nanotechnology that has commercial and environmentally friendly advantages in compare to chemical and physical approaches to nanometal synthesis. With increasing interest in the minimization of waste and implementation of sustainable processes in the adoption of all important principles of 'green' chemistry, the development of eco-friendly, simple, and economical methods for the preparation of advanced materials is necessary. Moreover, biological synthesis of metal nanoparticles has several important advantages over chemical synthesis such as larger quantities and lower costs of production (Parikh, Singh, Prasad, Patole, Sastry \& Shouche 2008).

Information on the use of extracts of marine algae to synthesize metallic nanoparticles, silver particularly is scant. Because of its abundance and ready availability, marine algae are good and economical sources of phytochemicals that can be exploited for the synthesis of metallic nanoparticles, but they have been less studied in comparison with other biosources such as plants and microbes. The increased popularity of these particles in marketable products is because of their discharge of free silver ions $\left(\mathrm{Ag}^{+}\right)$, that are identified to be antibacterial substances (Luoma, 2008). Recently, Wang, Chen, Li, Shao \& Peijnenburg (2012) indicated quantitatively that $\mathrm{Ag}^{+}$contributed to the toxicity of nanosilver colloids in 3 aquatic species at dissimilar trophic stages due to alterations in mechanisms of action.

Due to antibacterial and antifungal properties of silver nanoparticles (AgNPs), they have been used broadly as a biocide, water purification, food packaging and in many individual care products (Sotiriou \& Pratsinis, 2010). Previously, colloidal silver such as collargol (protein-stabilized nanosilver) was used for several medical purposes (Fung \& Bowen, 1996). Benn \& Westerhoff (2008) showed that AgNPs can be released into domestic wastewater by laundering of socks that are treated with AgNPs. According to Mueller \& Nowack (2008), around 500 tons of nanosilver is produced each year. Therefore, due to its leaching from consumer products, besides through industrial waste streams, there is a high risk of environmental pollution by nanosilver. Up to now, the acute test design has been applied globally for the screening of possibly hazardous chemicals and the 
examination of industrial effluents. Benefits of using Daphnia sp. toxicity test methods contain: easy to use in a laboratory situation, wellestablished culturing and test procedure, strong toxicity database, economical observation regime, small sample volume and quality control (Baird, Barber, Bradley, Calow. \& Soares 1989).

Daphnia magna, a freshwater zooplankton species, is a standard test organism for the toxicity protocols of the U.S. Environmental Protection Agency (EPA), International Standards Organization (ISO) and Organization for Economic Cooperation and Development (OECD 202 2004; OECD 211 2008). Comprehensive toxicity researches about Daphnia sp. were started and technique adjustment was advanced in the 1980s (Baird et al. 1989).

Sargassum boveanum is one of the species of marine plants that have distribution in the Indian Ocean (Iran, Saudi Arabia, Qatar and Kuwait) (silva, Basson \& Moe 1996). The sea lettuces comprise the genus Ulva, a group of edible green algae that is widely distributed along the coasts of the world's oceans. Ulva flexuosa is a species of seaweed in Ulvaceae family that can be found worldwide (Asia, Africa, Europe, Americas) (Hardy \& Guiry 2003, Burrows 1991). Sam, Palanichamy, Chellammal, Kalaiselvi \& Subramanian (2015) reported that Biosynthesis of silver nanoparticles was done with 11 species macroalgae green, red and brown algae. Ulva lactuca is one of the best seaweed for biosynthesis of silver nanoparticles, is known to have antimicrobial effects and its toxicity $\left(\mathrm{LC}_{50}\right)$ for Artemia salina was $1 \mu \mathrm{g} \mathrm{mL}^{-1}$.

Many researchers stated that biosynthetic nanoparticles can be less toxic for aquatic animals and are more friendly to the environment (Sam et al. 2015; Kumar, Senthamil selvi, Lakshmi prabha, Selvaraj, Macklin Rani, Suganthi, Sarojini Devi \& Govindaraju 2012). Then in this study, the acute toxicity of biosynthetic nanosilver's produced by seaweeds (Sargassum and Ulva) were compared with commercial chemosynthetic nanosilver.

\section{Materials and Methods}

Two methods were used for preparing silver nanoparticles:

1. Chemical nanoparticle $($ Trade name $=$ Nanosid L2000) that purchased from Nanonasbe Pars co, Iran.

2. Biosynthetic nanosilver with seaweeds ( $S$. boveanum and $U$. flexuosa) that were made in the laboratory. This process was done according to Kumar method in two different steps including:

\section{Preparation of seaweed extract}

The seaweed $S$. boveanum and $U$. flexuosa were collected manually from southeast offshore of Persian Gulf, Chabahar city, Sistan and Baluchestan province, Iran, and thoroughly washed in sea water to remove detritus and cleaned algae then washed in distilled Water and shade dried for five days. Fifty grams of powder sample was mixed into 1 liter of deionized water and the mixture was boiled for ten minutes. After cooling, the extract was 
filtered with Whatman no.1 filter paper. The extract was stored at $4{ }^{\circ} \mathrm{C}$ for further use.

\section{Nanosilver biosynthesis}

$900 \mathrm{~mL}$ of $1 \mathrm{mM}$ silver nitrate (AgNO3, Nanonasb Pars co.) solution was prepared and added to $100 \mathrm{~mL}$ of seaweed extract in a conical flask. The extract was incubated at room temperature $\left(25^{\circ} \mathrm{C}\right)$ for 24 hours exposed to direct natural sunlight. The reaction solution color changes were observed for the characterization of silver nanoparticles. Then, biosynthetic nonosilvers were purified by centrifuging at $8,000 \mathrm{rpm}$ and rinsed with redispersed with same aliquot of deionized water (Kumar, Senthamil Selvi \& Govindaraju 2012). Transmission Electron Microscopic (SEM) analysis was done by using a transmission electron microscopy (Philips, CM-30) for characterizing size and shape of biosynthesized silver nanoparticles.

\section{Evaluation of nanoparticles physicochemical specifications}

Characteristics of chemosynthetic colloidal nanosilver (Nanocid L2000), was as follow nanosilver concentration $4000 \mathrm{mg} \mathrm{L}^{-1}$, size of silver particles $8 \pm 0.78 \mathrm{~nm}$. Zeta potential $53 / 33 \pm 7 / 86 \mathrm{Mv}$ average, $\mathrm{pH} 4.2$ and geometric mean diameter 12/65 $\pm 1 / 46 \mathrm{~nm}$ (Asghari, Johari, Lee, Kim, Jeon, Choi, Moon \& Yu 2012).

Biosynthetic production of nanosilver was done using $S$. boveanum and $U$. flexuosa extraction and $\mathrm{AgNO} 3$ salt, then the size and quality of nanoparticles evaluated by Particle size analyzer apparatus (model: Scatterscope I quit), TEM (LEO, Co. model: 906E) .

\section{Experimental design}

Three silver nanoparticles including one chemical origin $(\mathrm{CPN})$ and two biosynthetic origins (SPN and UPN) were evaluated and compared for their environmental toxicity using D. magna (environmental pollution indicator) through Organization for Economic Cooperation and Development (OECD), Test guideline No: 211. D. magna was purified using parthenogenesis in one individual according to the guideline. Then purified daphnia transferred to 6-Well Cell Culture Plates, exposed to eight concentration (Table 1) of each nanosilver in triplicates for 48 hours. Water temperature was $25 \pm 1^{\circ} \mathrm{C}$.

Table 1. The selected concentrations of Chemo and Biosynthetic nanosilver to determine their acute toxicity for D. magna

\begin{tabular}{lcccccccccc}
\hline Treatment & $\begin{array}{c}\text { Total } \\
\text { D. magna }\end{array}$ & \multicolumn{7}{c}{ Concentration (mg L $\left.\mathbf{~}^{-1}\right)$} \\
\hline $\begin{array}{l}\text { Chemosynthetic Nanosilver } \\
30\end{array}$ & 0 & 0.006 & 0.013 & 0.025 & 0.05 & 0.1 & 0.2 & 0.4 & 1 \\
\hline $\begin{array}{l}\text { Biosynthetic Nanosilver by } \\
\text { Sargassum }\end{array}$ & 30 & 0 & 0.5 & 1 & 2 & 3 & 4 & 5 & 10 & - \\
\hline $\begin{array}{l}\text { Biosynthetic Nanosilver by } \\
\text { Ulva }\end{array}$ & 30 & 0 & 1 & 2 & 5 & 10 & 20 & 25 & 30 & - \\
\hline
\end{tabular}

\footnotetext{
${ }^{4}$ Transmission Electron Microscopy 


\section{Statistical analysis}

Maximum Acceptable Concentration (MAC) determined for each nanosilver. The mortality rate after $12 \mathrm{~h}, 24 \mathrm{~h}, 36 \mathrm{~h}$, and $48 \mathrm{~h}$ were recorded and analyzed using Probit analysis software, SPSS 16.0 version (Statistical software package - SPSS Inc., Chicago, IL, USA), then $\mathrm{LC}_{10}$, $\mathrm{LC}_{50}, \mathrm{LC}_{90}$ were measured to find the regression equation values. Results with $\mathrm{p}<0.05$ were considered to be statistically significant.

\section{Results}

The results of TEM images of silver nanoparticles biosynthesized from $S$. boveanum showed shape spherical nanoparticles (Fig. 1). The apparatus of particle size analyzers estimated the average size of $S$. boveanum and $U$. flexuosa nanoparticles $2.9 \mathrm{~nm}$ and $5.39 \mathrm{~nm}$, respectively (Table 2).
Acute toxicity of this nanosilver was different in D. magna. The $\mathrm{LC}_{50}$ in $48 \mathrm{~h}$ of biosynthetic nanosilver (S. boveanum and Ulva. Flexuosa origin) and chemical nanosilver in Daphnia were $1.03,3.24$ and $0.03 \mathrm{mg} \mathrm{L}^{-1}$ respectively. The mortality rate in biosynthesized nanosilver from $U$. flexuosa $\left(\mathrm{LC}_{50}=3.24 \mathrm{mg} \mathrm{L}^{-1}\right)$ was lower than other nanosilver and was 108 times lower than chemosynthetic nanoparticle $\left(\mathrm{LC}_{50}=0.03 \mathrm{mg}\right.$ $\left.\mathrm{L}^{-1}\right)$ (Fig 4). The mortality rate of D. magna enhanced in the chemosynthetic nanosilver, along with increasing concentration and exposure duration (Fig 2). In biosynthetic nanoparticles of Ulva (Fig 4), the maximum mortality rate at $\mathrm{LC}_{90} 12 \mathrm{~h}$ was $25.72 \mathrm{mg} \mathrm{L}^{-1}$, while in chemosynthetic nanoparticle was 1.32 $\operatorname{mg~L}{ }^{-1}$ (Fig. 2).

Table 2. The results of particle size of Chemo and Biosynthetic nanosilver product by two algae, S. boveanum and U.Flexuosa

\begin{tabular}{lllll}
\hline Type of nanoparticles & Mean \pm Span $^{*}$ & d (10) $^{* * *}$ & d (50) $^{* * * *}$ & d (90) $^{* * * * *}$ \\
\hline Biosynthetic Nanosilver by S. boveanum & $2.9 \pm 1.99$ & 1.42 & 2.90 & 7.2 \\
\hline Biosynthetic Nanosilver by U.flexuosa & $5.39 \pm 0.98$ & 3.49 & 5.39 & 8.77 \\
\hline Nanosilver L2000 & $7.1 \pm 1.49$ & 3.66 & 7.1 & 11.92 \\
\hline
\end{tabular}

*Span shows how the emission of particles and is obtained from d50 (d90-d10) and has the role of standard deviation (STED) in statistical calculations.

**The average particle diameter of the first decile (10\% of particles with the smallest diameter).

$* * *$ The average particle diameter of the half $(50 \%)$ of particles.

$* * * *$ The average particle diameter of the ninth decile ( $90 \%$ of particles).
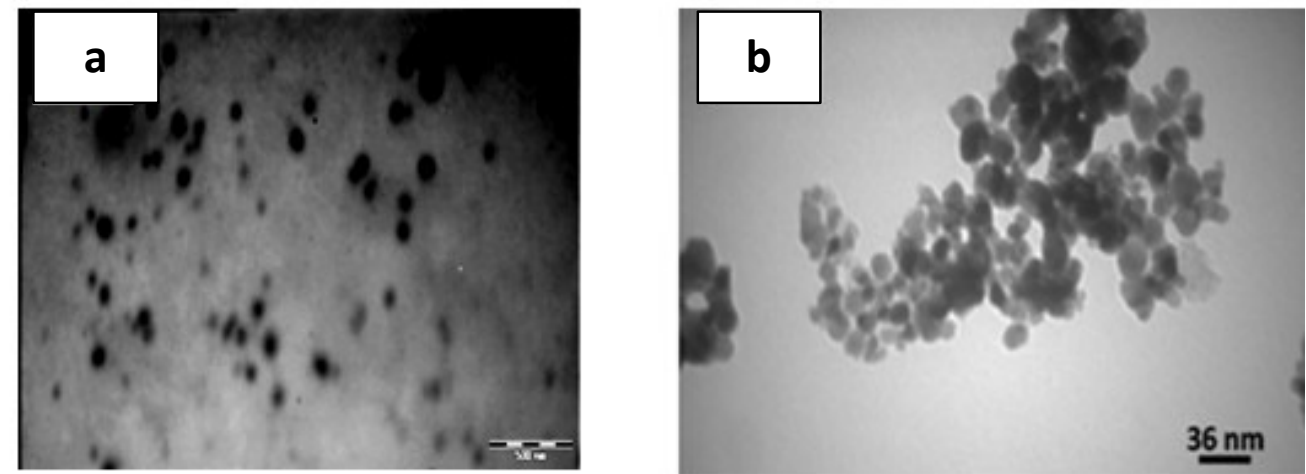

Figure 1. TEM picture of the biosynthetic nanoparticle of $S$. boveanum (a) and chemosynthetic nanoparticle (b). 


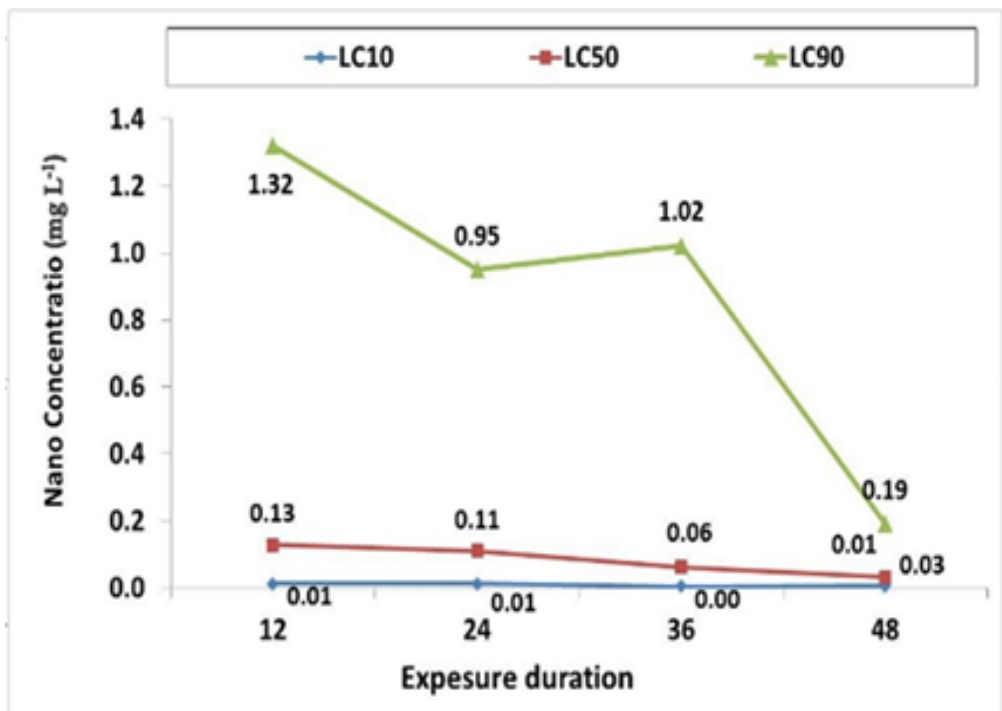

Figure 2. Mortality rate of D. magna in chemosynthetic nanosilver treatment.

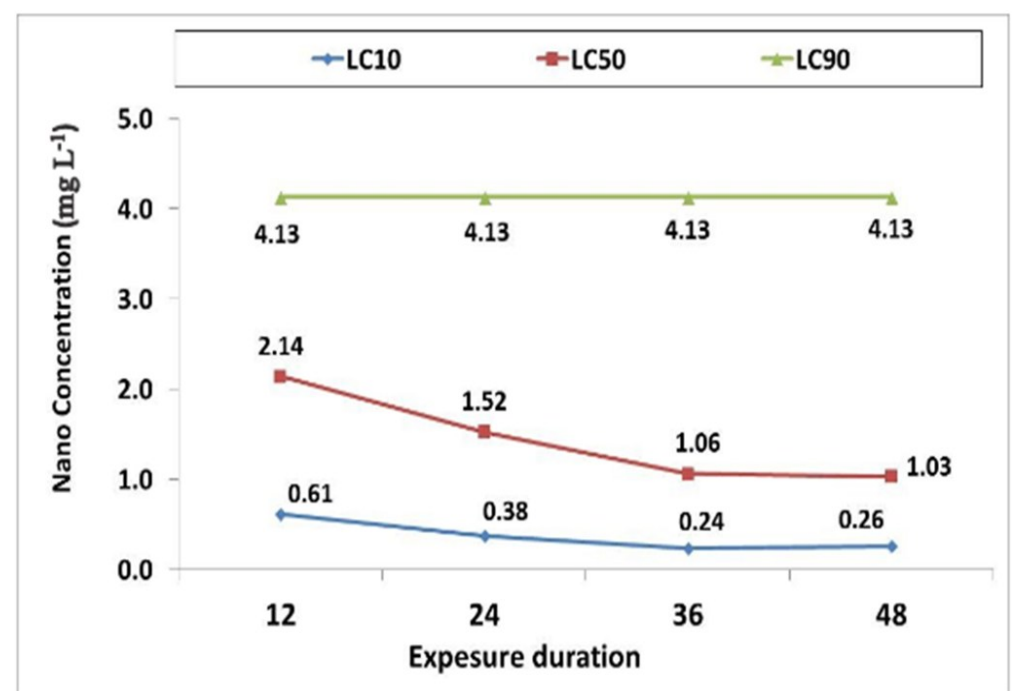

Figure 3. Mortality rate of D. magna in biosynthetic nanosilver treatment by S. boveanum.

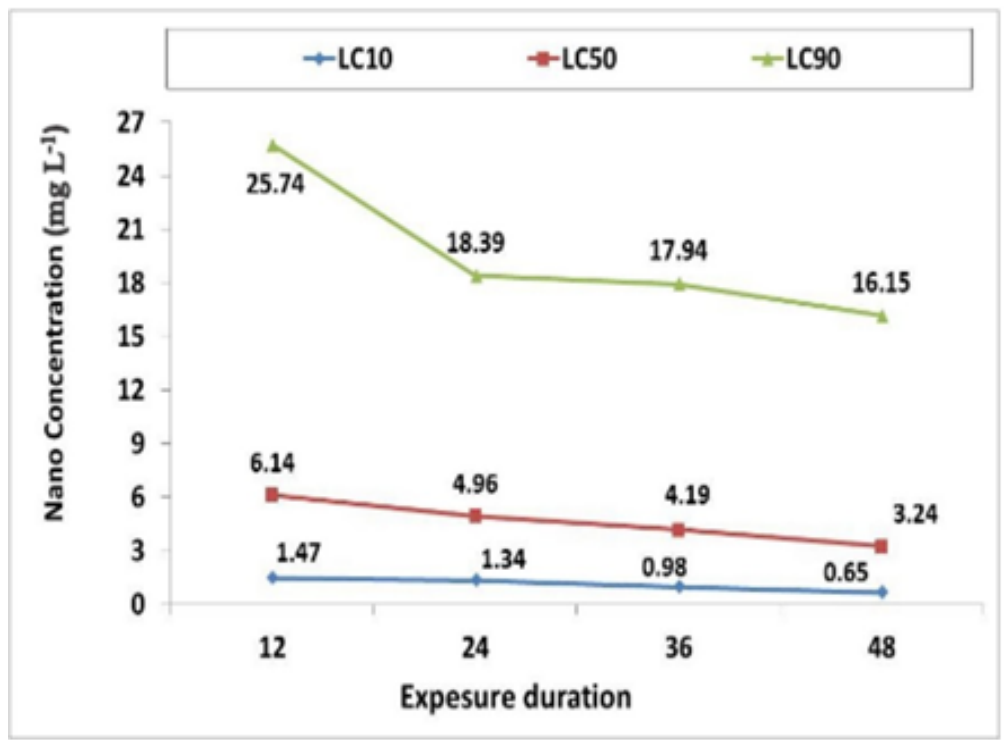

Figure 4. Mortality rate of D. magna in biosynthetic nanosilver treatment by $U$. flexuosa. 


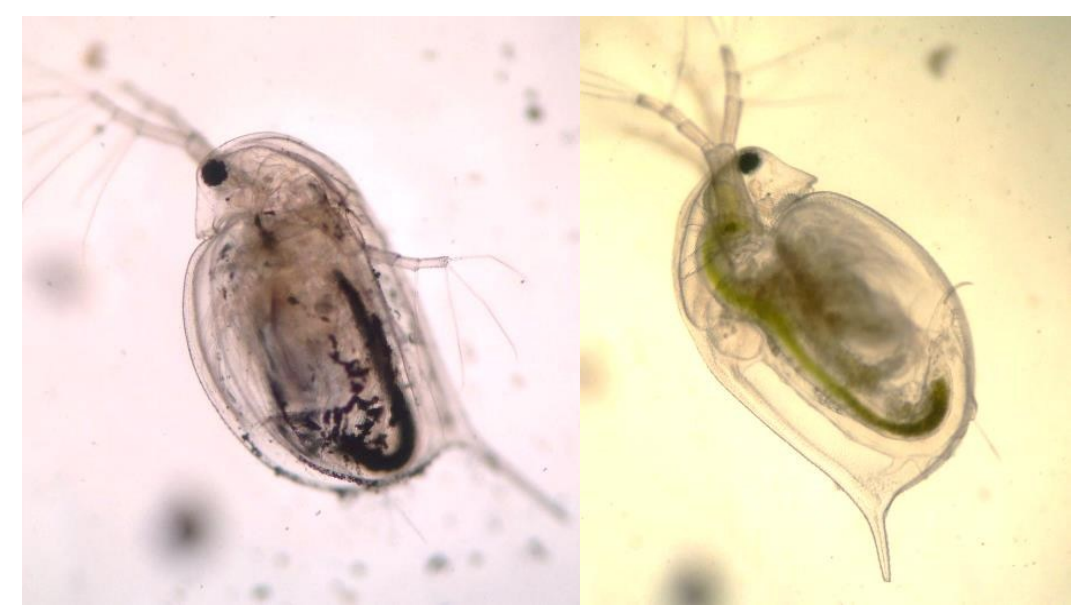

Figure 5. Left picture is D. magna that absorbed nanosilver (note to accumulation of nanoparticles in gut), right picture is $D$. magna without nanosilver, (Taken by light microscope).

\section{Discussion}

One of the common methods of toxicity assessment test (Toxicity bioassay) is the usage of standard model organisms such as Daphnia magna, zebrafish and Artemia spp. (Nunes, Carvalho, Guilhermino \& Stappen 2006). Both size biogenic (biosynthesized by Sargassum boveanum) and chemical of silver nanoparticles were in the range of $7 \pm 1 \mathrm{~nm}$ (fig1 b) and a spherical shape. Many types of research were founded that function of biosynthesized nanoparticles toxicity depends on the size, physicochemical properties (electrical charge, crystal structure, solubility, area surface material, shape, and morphology) and their in vivo behavioral (Lapresta-Ferna'ndez, Ferna'ndez \& Blasco 2012; Gatoo et al. 2014). So basically, particle size influence distribution and penetration of nanoparticles in biological systems (Lovri'c, Bazzi, Cuie, Fortin, Winnik \& Maysinger 2005) and future hazards of nanoparticles with sizes smaller than $10 \mathrm{~nm}$, are more disturbing (Gatoo, Naseem, Arfat, Dar, Qasim \& Zubair 2014).
Moreover, biosynthesis of silver nanoparticles extracts of $U$. flexuosa seaweed has medium size range $5.39 \mathrm{~nm}$, the circular shape and the size of the average diameter of between $2 \mathrm{~nm}$ to $32 \mathrm{~nm}(15 \pm 1 / 5)$. In addition, Vijayan, Santhiyagu, Singamuthu, Kumari Ahila, Jayaraman and Ethiraj (2014) were obtained the size and shape silver nanoparticles extract of Turbinaria conoides seaweed ranging between 2-17 $\mathrm{nm}$ and spherical shape respectively. Nanoparticles extracted from $U$. flexuosa showed the medium size of $5.39 \mathrm{~nm}$ (Fig. 1a) spherical shape (Fig. 2) while having consistent with the relevant studies.

Nano Particles can enter through the cell membrane by simple diffusion process or cell wall proteins and receptors. These materials create a membrane electrochemical gradient interference, cause disruption in electrons generation in the respiratory chains, which cause generation of $\mathrm{ROS}^{5}$. ROS cause lipid peroxidation, changes in proteins, antioxidant enzymes generation, DNA damages, and

\footnotetext{
${ }^{5}$ Reactive Oxygen Species
} 
ultimately creating a break in the path of ion transport, membrane changes and increasing its permeability, lead to entrance NPs to the cells inside, which lead to apoptosis and cell death (Lapresta-Ferna'ndez, Ferna'ndez \& Blasco 2012). Hence the increase in mortality rates of D. magna, along with increasing the Nps concentration and exposure duration, can be caused by the production of ROS and oxidative stress effects.

Griffitt, Luo, Gao, Bonzongo \& Barber (2008) reported that $\mathrm{LC}_{50}$ of silver nanoparticles (AgNPs) with size of 20 to $30 \mathrm{~nm}$ and spherical shape in two Daphnia species (adult Daphnia pulex and neonates Ceriodaphnia dubia) at 48 hours, were 0.040 and $0.067 \mathrm{mg} \mathrm{L}^{-1}$ while in silver metal solution $\left(\mathrm{Ag}^{+}\right)$were 0.008 and $0.16 \mathrm{mg} \mathrm{L}^{-1}$ respectively. We were obtained $\mathrm{LC}_{50}$ of chemical silver nanoparticles (AgNPs) around $0.03 \mathrm{mg} \mathrm{L}^{-1}$ in $D$. magna at 48 hours (fig 3), while its value was close to adult Daphnia pulex (0.04 $\left.\mathrm{mg} \mathrm{L}^{-1}\right)$.

Kumar et al. (2012) assessed the effects of silver nanoparticles biosynthesized from extracts of Sargassum ilicifolium by Artemia salina mortality test. They reported $\mathrm{LC}_{50}$ at 48 hours $1.08 \mathrm{mg} \mathrm{L}^{-1}$ which its value is close to the toxicity of biosynthesized nanosilver from Sargassum boveanum in D. magna in our work (1.03 $\mathrm{mg} \mathrm{L}^{-1}$ ) (fig4).

Due to the test species, the toxicity of nanosilver is measured varied. For instance, the latest review by Kahru \& Dubourguier (2010) revealed that AgNPs were toxic to algae and crustaceans even at very low concentration $\left(\mathrm{EC} 50<1 \mathrm{mg} \mathrm{L}^{-1}\right.$ ), however the toxicity to protozoa was fairly low, EC5 $=40 \mathrm{mgAg} \mathrm{L}^{-1}$.
The mechanism of $\mathrm{Ag}^{+}$toxicity in aquatic organisms is ion regulatory disturbance or failure related to competitive or noncompetitive inhibition of sodium or potassium iondependent adenosine triphosphates $\left(\mathrm{Na}^{+}, \mathrm{K}^{+}\right.$ATPase) activity. This inhibits $\mathrm{Na}^{+}$uptake at the gills, that leads to an arrangement of actions ending in cardiac arrest and death (Hogstrand \& Wood 1998, Bianchini \& Wood 2003) Zhao and Wang, (2013) indicated that soluble $\mathrm{Ag}^{+}$ released from AgNPs through preventing sodium uptake was toxic to D. magna. Moreover, Shen, Zhou, Yang, Chao, Liu \& Liu (2015) were calculated the $\mathrm{LC}_{50}$ of $\mathrm{AgNO}_{3}$ in Daphnia magna at around 0.58-2.51 $\mu \mathrm{g} \mathrm{\textrm {L } ^ { - 1 }}$. which is lower than our results. This different results can be related to the difference in Daphnia strain, water physicochemical parametersicle and even nanoparticles characteristics. Ribeiro, Gallego-Urrea, Jurkschat, Crossley, Hassellöv, Taylor, Soares \& Loureiro (2014) were calculated $24 \mathrm{~h} \mathrm{LC}_{50}$ of AgNP and AgNO3 in D. magna as: $11.41 \mu \mathrm{g} \mathrm{L}^{-1}$ and $1.36 \mu \mathrm{g} \mathrm{L}^{-1}$, respectively, while the $48 \mathrm{~h}-\mathrm{LC}_{50}$ for $\mathrm{AgNP}$ and $\mathrm{AgNO} 3$ were $11.02 \mu \mathrm{g} \mathrm{L}{ }^{-1}$ and $1.05 \mu \mathrm{g} \mathrm{L}^{-1}$, respectively.

Kumar et al. (2012) showed that Artemia salina and heterotroph bacteria have less mortality in the silver nanoparticle biosynthesized by Sargassum iliifolium. In the current research, we obtained that less mortality in the silver nanoparticle biosynthesized by $\mathrm{S}$. boveanum and $U$. flexuosa on the D. magna (fig 4 and 5).

Zhao \& wang (2012) have compared the toxicity of three surface coated nanosilver's including lactate, polyvinylpyrrolidone, and sodium dodecyl benzene sulfonate nanosilver (as 
AgNPs-L, AgNPs-P and AgNPs-S, respectively) in Daphnia magna. They reported $\mathrm{LC}_{50} 48 \mathrm{~h}$ concentration of AgNPs-L, AgNPs-P and AgNPs-S around 28.7, 2.0 and $1.1 \mu \mathrm{g} \mathrm{L^{-1 }}$ respectively, While AgNPs showed less mortality rate. In this research calculated AgNPs of Sargassum boveanum (0.03 $\mathrm{mg} \mathrm{L}^{-1}$ ) (fig 4) was similar to AgNPs lactate $\left(28.7 \mu \mathrm{g} \mathrm{L}^{-1}\right)$.

As a conclusion, nanosilver from $U$. flexuosa was less toxic and more environmental friendly than AgNPs synthesized from Sargassum boveanum, although both biosynthesized AgNPs showed significant lower toxicity than chemical nanosilver, then it is highly recommended to produce biosynthesized nanoparticles from marine algae as a proper alternative to chemical nanosilver.

\section{Acknowledgements}

This research was financially supported by the Research Council of Shahid Chamran University of Ahvaz, Ahvaz, Iran.

\section{References}

Asghari S., Johari S.A., Lee J.H., Kim Y.S., Jeon Y.B., Choi H.J., Moon M.C. and Yu I.J. (2012) Toxicity of various silver nanoparticles compared to silver ions in Daphnia magna. Journal of Nanobiotechnology 2, 10 (1):14.

Baird D.J., Barber I., Bradley M., Calow P. and Soares A.V.M. (1989) The Daphnia bioassay: a critique., Hydrobiologia 188/189, 403-406.

Benn T.M. and Westerhoff P. (2008) Nanoparticle silver released into water from commercially available sock fabrics. Environmental Science and Technology 42, 4133-4139.

Bianchini A. and Wood C. (2003) Mechanism of acute silver toxicity in Daphnia magna. Environmental Toxicology and Chemistry 22, 1361-1367.

Burrows E.M. (1991) Seaweeds of the British Isles. Volume 2 Chlorophyta. Natural History Museum Publications. London ISBN 0-56500981-8

Fung M.C. and Bowen D. (1996) Silver products for medical indications: risk-benefit assessment. The Journal of Clinical Toxicology 34, 119-126.

Gatoo M.A., Naseem S., Arfat M.Y., Dar A.M., Qasim K. and Zubair S. (2014) Physicochemical properties of nanomaterials: implication in associated toxic manifestations. BioMed Research International 6, 1-8.

Griffitt R.J., Luo J., Gao J., Bonzongo J.C., and Barber D.S. (2008) Effects of particle composition and species on toxicity of metallic nanomaterials in aquatic organisms. Environmental Toxicology and Chemistry 9, 1972-1978.

Hardy F.G. and Guiry M.D. (2003) A Checklist and Atlas of the Seaweeds of Britain and Ireland.The British Phycological Society. ISBN 09527115 16. p 29.

Hedayati A., Kolangi H., Jahanbakhshi A., and Shaluei F. (2012) Evaluation of silver 
nanoparticles ecotoxicity in silver carp (Hypophthalmicthys molitrix) and goldfish (Carassius auratus). Bulgarian Journal of Veterinary Medicine 15, 172-177.

Hogstrand C. and Wood C.M. (1998) Towards a better understanding of the bioavailability, physiology and toxicity of silver to fish: Implications for water quality criteria. Environmental Toxicology and Chemistry 17, $572-578$.

Kahru A. and Dubourguier H.C. (2010) From ecotoxicology to nanoecotoxicology. Toxicology 269, 105-119.

Kumar P., Senthamilselvi S., Lakshmi prabha A., Selvaraj S., Macklin Rani L., Suganthi P., Sarojini Devi B. and Govindaraju M. (2012) Antibacterial activity and In-vitro cytotoxicity assay against brine shrimp using silver nanoparticles synthesized from Sargassum iliifolium. Digest Journal of Nanomaterials and Biostructures 7, 1447-1455.

Kumar P., Senthamilselvi S., Lakshmi Prabha A., Premkumar K., Muthukumaran R., Visvanathan P., Ganeshkumar R.S. and Govindaraju M. (2012a) Efficacy of biosynthesized silver nanoparticles using Acanthophora spicifera to encumber biofilm formation. Digest Journal of Nanomaterials and Biostructures 7, 511-522.

Kumar p., Senthamil Selvi S. and Govindaraju M. (2012) Seaweed-mediated biosynthesis of silver nanoparticles using Gracilaria corticata for its antifungal activity against Candida spp. Applied Nanoscience 3(6), 495-500.

Lapresta-Ferna'ndez A., Ferna'ndez A. and Blasco J. (2012) Nanoecotoxicity effects of engineered silver and gold nanoparticles in aquatic organisms. Trends in Analytical Chemistry 32, 40-59.

Lovri'c J., Bazzi H.S., Cuie Y., Fortin G.R.A., Winnik F.M. and Maysinger D. (2005) Differences in subcellular distribution and toxicity of green and red emitting $\mathrm{CdTe}$ quantum dots. Journal of Molecular Medicine 83, 377-385.

Luoma S.N. (2008) Silver nanotechnologies and the environment: Old problems or new challenges. PEN 15. Project on Emerging Nanotechnologies, Woodrow Wilson International Center for Scholar, Washington, DC, p 65.

Mueller N.C. and Nowack B. (2008) Exposure modeling of engineered nanoparticles in the environment. Environmental Science and Technology 42, 4447-4453.

Nunes B.S., Carvalho F.D., Guilhermino L.M., Stappen G.V. (2006) Use of the genus Artemia in ecotoxicity testing. Environmental Pollution $144,453-462$.

OECD (Organisation for Economic Cooperation and Development) 202 (2004) OECD guidelines for the testing of chemicals. Daphnia $s p$, acute immobilization test. Paris, France 
OECD (Organisation for Economic Cooperation and Development) 211 (2008) OECD guidelines for the testing of chemicals. Daphnia $s p$., reproduction test. Paris, France.

Parikh R.Y., Singh S., Prasad B.L.V., Patole M.S., Sastry M. and Shouche Y.S. (2008) Extracellular synthesis of crystalline silver nanoparticles and molecular evidence of silver resistance from Morganella sp.: towards understanding biochemical synthesis mechanism. Journal of chemical biology 9, 1415-1422.

Ribeiro, F., Gallego-Urrea J.A., Jurkschat K., Crossley A., Hassellöv M., Taylor C., Soares A.M.V.M. and Loureiro S. (2014) Silver nanoparticles and silver nitrate induce high toxicity to Pseudokirchneriella subcapitata, Daphnia magna and Danio rerio. Science of the Total Environment 466-467, 232-241.

Sam N., Palanichamy S., Chellammal S., Kalaiselvi P. and Subramanian G. (2015) Antifouling effects of silver nanoparticles synthesized from tropical seaweeds. International Journal of Current Microbiology and Applied Sciences 4, 1029-1042.

Shen M.H., Zhou X.X., Yang X.Y., Chao J.B., Liu R., and Liu J.F. (2015) Exposure medium: key in identifying free $\mathrm{Ag} 1$ as the exclusive species of silver nanoparticles with acute toxicity to Daphnia magna. Scientific Reports 5, 1-8.
Silva P.C., Bassoon Ph.W. and Moe R.L. (1996) Catalogue of the Benthic Marine Algae of the Indian Ocean, University of California 79, 661.

Sotiriou G.A. and Pratsinis S.E. (2010) Antibacterial activity of nanosilver ions and particles. Environmental Science and Technology 44, 5649-5654.

Vijayan R.S., Santhiyagu P., Singamuthu M., Kumari Ahila N., Jayaraman R., and Ethiraj K. (2014) Synthesis and Characterization of Silver and Gold Nanoparticles Using Aqueous Extract of Seaweed, Turbinaria conoides, and Their Antimicrofouling Activity. The Scientific World Journal 2014, 1-11.

Wang Z., Chen J., Li X., Shao J. and Peijnenburg W.J. (2012) Aquatic toxicity of nanosilver colloids to different trophic organisms: Contributions of particles and free silver ion. Environmental Toxicology and Chemistry 31, 2408-2413.

Zhao C.M. and Wang W.X. (2012) Importance of surface coatings and soluble silver in silver nanoparticles toxicity to Daphnia magna. Nanotoxicology 6, 361-370.

Zhao C.M. and Wang W.X. (2013) Regulation of sodium and calcium in Daphnia magna exposed to silver nanoparticles. Environmental Toxicology and Chemistry 32, 913-919. 


\title{
بررسى سميت نانوذرات نقره در دافنى ماكنا (Daphnia magna): مقايسه توليد
} شيميايى و سنتز سبز سميت سابر

\author{
زهرا طولابى دزفولى'، مجتبى عليشاهى '"، امير آرامون '، سكينه مشجور' \\ ا كروه علوم درمانتاهي، دانشكده داميزشكى، داششَاه شهيد حمران اهواز، اهواز، ايران

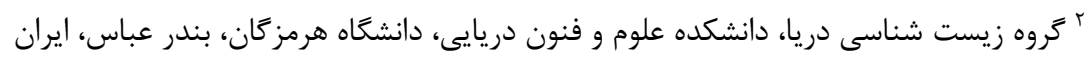

اخيراً نانوذرات به ويزه نانو ذرات نقره (AgNPs) به طور گسترده در صنعت استفاده مىشود، از اين رو آلودخى محيط زيست با نانو ذرات نقره موجب نكر انى زيادى شده است. در اين مطالعه سميت نانوذرات نقره بيوسنتزى توليد شده توسط دو ماكروجلبك، سار كاسوم بوونوم و اولوا فلكسوزا با نانو نقره شيميايى در دافنى ماكنا مقايسه شدند. اندازه و كيفيت نانوذرات توسط FT- TEM و تجزيه كننده اندازه ذرات ارزيابى كرديدند. آزمون سميت حاد با استفاده از OECD و راهنماى تست Iال؟ بررسى شد. دافنى ماكنا به روش بكرزايى از يك دافنى با توجه به استاندارد OECD تكثير داده شد. سبس دافنىها در معرض هشت رقت

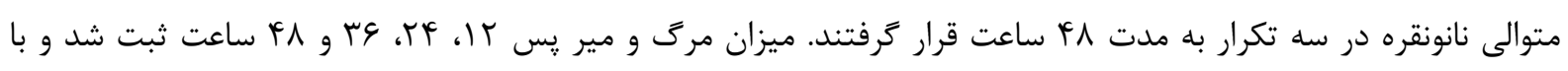
استفاده از نرم افزار يروبيت مورد تجزيه و تحليل قرار كرفت. نتايج نشان داد كه تمام نانوذرات نقره (بدون در نظر كرفتن منشاء سنتز آنها) در دافنى سمى و سميت حاد آنها متفاوت بود. ــ LC ب ساعته نانو ذرات بيوسنتزى ساركاسوم، اولوا و نانو نقره

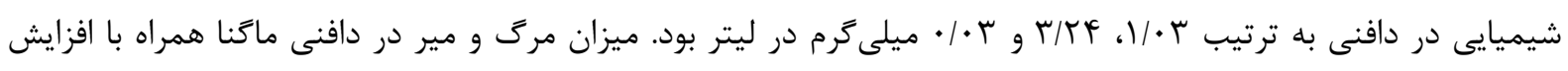
غلظت نانو ذرات نقره و مدت زمان در معرض قرار كرفتن در تمام گروهها، افزايش يافت. بالاترين سميت متعلق در كروه نانو نقره

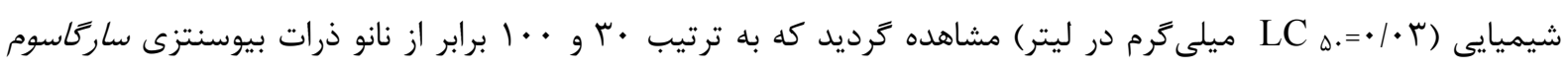

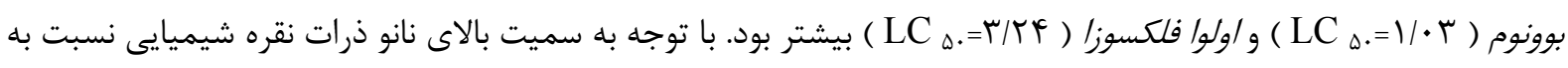
بيوسنتزى، جايگزين شدن نانوذرات بيوسنتزى به دليل دوستدار محيط زيست بودن پيشنهاد مى گردد. كلمات كليدى: نانو نقره، دافنى ماكنا، ساركاسوم بوونوم، اولوا فلكسوزا، بيوسنتز. alishahim@scu.ac.ir :نويسنده مسئول: 